\title{
Has Distance Learning Become More Flexible? Reflections of a Distance Learning Student
}

\author{
Theda Thomas \\ Australian Catholic University, Melbourne, Victoria, Australia
}

theda.thomas@acu.edu.au

\begin{abstract}
This paper provides insight into the way in which distance learning had changed over the past 30 years from the perspective of the author as a distance learning student. The question is then asked as to whether current practice is reducing flexibility for distance learning students? The paper starts with a discussion of flexible learning and the different factors that need to be considered when making distance learning flexible for students. The paper then describes the author's experiences as a distance learning student in the early 1980s and compares it to her experiences as a student in 2006-2008. The experiences were compared using various dimensions of flexibility. The main dimensions used were flexibility of content, assessment, instructional approach, course delivery, time, and learning styles. While flexibility had improved in some areas, improving the pedagogical design by engaging students on an ongoing basis had also decreased flexibility in others. The paper concludes with a look to the future and factors that online designers might consider in balancing different types of flexible learning activities.
\end{abstract}

Keywords: distance education, flexible learning

\section{Introduction}

The constructivist theory of learning proposes that learners need to be actively involved in and responsible for their own learning in order to make the cognitive links between the new material and their prior understanding (Ardito, Costabile, de Marsico, Lanzilotti, Levialdi Roselli, \& Rossano, 2006). Using a constructivist approach to learning would require an e-learning environment with appropriate levels of learner control and flexibility.

The need for flexibility in distance learning was recognised in the early 1980s (Baath, 1982; Marland, \& Store, 1982), but the technologies were not there to enable flexibility in the same way that they are today. In a recent editorial in the journal Distance Education, Bennet, Agostinho, Lockyer, and Harper (2009, p. 175) state that "online technologies have transformed traditional print-and-post distance education and enabled campus-based institutions to offer flexible study options." While the author would not disagree with this statement, her recent experiences as a student have led her to wonder how flexible distance education has become since she first became

Material published as part of this publication, either on-line or in print, is copyrighted by the Informing Science Institute. Permission to make digital or paper copy of part or all of these works for personal or classroom use is granted without fee provided that the copies are not made or distributed for profit or commercial advantage AND that copies 1) bear this notice in full and 2) give the full citation on the first page. It is permissible to abstract these works so long as credit is given. To copy in all other cases or to republish or to post on a server or to redistribute to lists requires specific permission and payment of a fee. Contact Publisher@InformingScience.org to request redistribution permission. a distance education student in the early 1980s. Hagel and Shaw (2006) say that it is often assumed that online study modes supported by Information and Communication Technologies (ICT) provide students with better flexibility and convenience, but do they really accomplish that? 
This paper provides insight into the way in which distance learning has changed over the past 30 years from the perspective of the author as a distance learning student. The question is then asked as to whether current practice is reducing flexibility for distance learning students. The paper starts with a look at the literature on flexible learning and what it entails. The paper then describes the author's experiences as a distance learning student in the early 1980s and compares it to her experiences as a student in 2006-2008. Various dimensions of flexibility of distance learning are used for the comparison. The paper concludes with a look to the future and factors that online designers might consider in balancing different types of flexible learning activities.

\section{What is Flexible Learning?}

There are many ways of looking at flexible learning. Many students want their studies to be flexible so that they can fit their studies around family or work commitments, study with a disability, or study in a remote area (Willems, 2005). Students want to be able to study at their own pace and in a variety of locations.

There is more to flexible learning than just considerations around where and when students study, however. As Bowles (2004) says the hallmark of flexible learning is that it should be able to adapt to individual learner's needs and circumstances. To be truly flexible, online designers also need to consider flexibility in how learning takes place, instructional methods, content, and ways in which students interact with the lecturer and fellow students. In 1993, Van den Brande (p.2) defined flexible learning as "enabling learners to learn when they want (frequency, timing, duration), how they want (modes of learning), and what they want (that is learners can define what constitutes learning to them)." Sadler-Smith and Smith (2004) take these concepts further and suggest that to be truly flexible, the learner needs to be the centre of our design and that flexible systems will cater for students with different cognitive styles, learning styles, and instructional preferences. This is supported by Willems (2005) who relates flexible learning to student-centred learning. Students learn in different ways, for example, some are visual while others prefer textual, some are self-directed, independent learners while others are dependent, some prefer collaborative learning and others to work individually. To be truly flexible instructional design needs to cater for all of these (Sadler-Smith \& Smith, 2004).

Distance education technologies have become more cost-effective over the years, and that means that teachers and students have access to a broad range of methods to help overcome any obstacles of time, place, and pace as well as helping students and staff to engage with one another in various ways (Baggaley, 2008). In the past five years technology has progressed to allow many options for student-student interaction and student-lecturer interaction, thereby ostensibly increasing the flexibility for course offerings. Tools like chat, video, discussion threads, application sharing, and group facilitation tools facilitate interaction between students and promote the use of group work (Trembaly, 2006). Willems (2005) questions whether these new technologies can constrain students and cause them undue frustration. Some of this frustration was experienced by the author and led to her investigating this topic.

There are various dimensions to flexible learning. Nikolova and Collis (1998) mention 5 categories of flexible learning, namely, time, content, instructional approaches, course delivery methods, and entry requirements. They expand time to cater for the dimensions of time when the course beings, times for participation within the course, the learner's pace through the course, and timing of assessment. They take the category of content and divide into it the flexibility dimensions of flexibility of topic, sequence, amount of learning activities, level of difficulty, and assessment standards. They suggest that entry requirements and prerequisites for a course can also be flexible in allowing various pathways into the course. The dimensions of instruction approaches and learning materials are given as social organisation (individual or group), language of communication, flexible formats for learning materials, and the pedagogy and role that the in- 
structor plays. Course delivery can be flexible along the times and places for support, methods of obtaining support, types of support, place where students can study, and flexible delivery channels.

Nikolova and Collis' (1998) and Sadler-Smith and Smith's (2004) work have been used as a basis for the comparison provided later in the document. Entry requirements were not considered relevant to the discussion. The six main dimensions of flexibility addressed are content, assessment, instructional approach, course delivery, time, and learning styles.

A discussion of how technology has changed over the past thirty years is outside of the scope of this paper. When discussing the advantages of using technology for learning, the ability to be flexible with time and space and the ability to adapt to the individual student are often listed at the top of the list (Dalsgaard, 2005). Most people would agree that current technologies offer many options for the lecturer to offer the students an engaging, flexible experience. The question raised here is whether the use of these technologies increases or reduces flexibility of the learner's experience?

The following sections briefly describe my experience as a student in 1982-1983 and again in 2006-2008. As this is my story, I have chosen to write it in the first person. In order to understand my experiences as a student it is important to understand my learning styles. I will explain my situation at the time of studying with the two different descriptions. I consider myself an independent, self-directed learner rather than one that is dependent. I am able to look at data from both a holistic and an analytical perspective. While I enjoy interacting with others, I prefer to study and do assessment individually. I tend to prefer written materials to visual. This study was a voyage of discovery for me as I started to "prove" that distance learning had become inflexible and ended by realising that while one aspect of the study might have become more inflexible overall I had been given a wide variety of flexible experiences in my later studies.

\section{My Distance Learning Story $1982-1983$}

In 1982, I decided that I needed to upgrade my Bachelor of Science degree to a Bachelor of Science (Honours) degree in the discipline of Information Systems. If I had been able to do this full time, it would have been a one year program, but I was working full time so I decided to do it in two years, part time. I enrolled by distance at a distance education university.

I enrolled for my Bachelor of Science (Honours) degree in December of 1981 and received the study materials for the course within a couple of weeks of enrolling. I was studying five subjects per year for two years. Along with the study materials, I received my assignments for the year. Each subject had 3 to 4 assessments and an examination. The University required satisfactory completion of assignments in order to write examinations.

I knew it was going to be a tough year and set to studying right away. Each subject had a paperbased study guide, and we were expected to use our textbook and additional reading when answering assignments and studying the various topics. We would order copies of articles and books from the university library when we needed them.

As I had received my study materials in December, I was able to put together a study program for the entire year. I knew when the pressure times were at work and gave myself some slack during those times. At other times, I would ensure that assignments were due on time or early.

All materials were paper-based and I would do most of my reading on the bus on the way to and from work. I would work on the assignments at night and over the weekend. I found a friend who was undertaking some of the same subjects as I was, and we would discuss some of the work and help each other when we got stuck. When we had a problem we would contact the lecturer who would help us over the phone. 
With five subjects, some assignments were due at the same time as others, but I was able to plan my studies to ensure that I completed some of the assignments in advance so that I did not end up trying to finish them all at once. This left me with time at the end of the year to review old examination papers and review the materials before exams in November.

\section{My Distance Learning Story 2006 - 2008}

I decided to enrol in a Graduate Certificate in Higher Education. This Certificate was offered online, and we were expected to do two subjects per year (one each semester.) The first subject was offered from October 2006 to December 2006 over a 12 week period.

Online materials were usually made available to us one week prior to the start of the semester. In some cases we were able to get some information about the textbook prior to the semester. Each semester was 12 weeks. We had access to journals and articles through the library's electronic resources. The first three subjects were basically run in the same way with the fourth subject being a research project. I will discuss my experiences with the first three subjects here.

As the subjects were not run concurrently, I did not have to worry about multiple assignments being due at the same time. The first three subjects all included written assignments and an assignment based on our discussion groups and reflections. In some cases there was a discussion every week and in others every two weeks. In one of the subjects, we undertook a group assignment. There were no examinations.

\section{Comparing My Experience with Respect to Flexibility}

Many articles have been written about evaluating e-learning systems and approaches to e-learning (Ardito et al., 2006; Ozkan \& Koseler, 2009). This study did not attempt to evaluate the whole experience or to evaluate the use of the technology itself. The methodology used for this research was a personal journey of exploration. The author's own experience led her to investigate what the term flexibility of learning meant and to then undertake the comparison.

The literature study identified seven dimensions of learning, namely, entry requirements, content, assessment, instructional approach, course delivery, time, and learning styles (Bowls, 2004; Nikolova \& Collis, 1998; Sadler-Smith \& Smith, 2004). The issue of entry requirements was not considered as it is not affected by the use of a technology environment. The other six dimensions were investigated further and Table 1 gives an overview of the dimensions and sub-dimensions used. 


\begin{tabular}{|l|l|}
\hline \multicolumn{2}{|c|}{ Table 1: Dimensions of flexibility } \\
\hline Dimension & Sub-dimensions \\
\hline Content & $\begin{array}{l}\text { Topics covered } \\
\text { Sequencing of topics } \\
\text { Expectations regarding number and types of learning experiences }\end{array}$ \\
\hline Assessment & $\begin{array}{l}\text { Assessment methods fixed or choice } \\
\text { Types of assessment } \\
\text { Assessment criteria fixed or negotiated } \\
\text { Individual / Group assignments }\end{array}$ \\
\hline Instructional Approach & $\begin{array}{l}\text { Social organisation of learning } \\
\text { Formats of learning materials } \\
\text { Role of the instructor } \\
\text { Feedback methods from instructor }\end{array}$ \\
\hline Course Delivery & $\begin{array}{l}\text { Communication with the lecturer } \\
\text { Types of support available } \\
\text { Place for study }\end{array}$ \\
\hline Time & $\begin{array}{l}\text { Starting time of subject } \\
\text { Times for participation within the subject } \\
\text { Learners pace themselves } \\
\text { Timing of assessment }\end{array}$ \\
\hline Learning Styles & $\begin{array}{l}\text { Autonomy (dependent vs. independent learner) } \\
\text { Mode preference (verbal vs. visual) } \\
\text { Collaborative vs. Individual }\end{array}$ \\
\hline
\end{tabular}

After identifying the categories for the evaluation of flexibility I evaluated my experiences as a student for the years 1982-1983 compared to the years 2007-2008. These are based on my personal experience and do not necessarily reflect the experiences of all students.

\section{Content}

When evaluating my experience regarding the flexibility of content, I found that the content was much more flexible in recent years than it was in the 1980s with regard to what was taught and being able to choose between different options regarding content. Table 2 compares my experiences.

\begin{tabular}{|l|l|l|}
\hline \multicolumn{2}{|c|}{ Table 2: Comparison of flexibility for content category } \\
\hline Flexibility Dimension & 1982-1983 experience & 2007-2008 experience \\
\hline Topics covered & Fixed & $\begin{array}{l}\text { Mostly fixed but some ability to adapt the } \\
\text { content to our own experience. Choice of } \\
\text { modules in some subjects. }\end{array}$ \\
\hline Sequencing of topics & Largely fixed & $\begin{array}{l}\text { Fixed as participation meant you had to do } \\
\text { what was required in a particular week. }\end{array}$ \\
\hline $\begin{array}{l}\text { Expectations regarding } \\
\text { number and types of } \\
\text { learning experiences }\end{array}$ & $\begin{array}{l}\text { Besides assignments student } \\
\text { chose how much to study and } \\
\text { how to study }\end{array}$ & $\begin{array}{l}\text { Many of the learning experiences were } \\
\text { online thus raising expectations regarding } \\
\text { participation in a particular method chosen } \\
\text { by the lecturer. }\end{array}$ \\
\hline
\end{tabular}

There was little flexibility, however, regarding the sequencing of topics as we were required to take part in interactions with others on a regular basis and were required to study specific topics in sequence in order to participate. In the 1980s I was able to skip topics that I already knew or study things in different orders as long as my assignments were completed in a timely fashion. In the 1980s we were provided with a number of learning tasks and chose which ones to participate in. As a student I would normally undertake all of the learning activities, but it was my choice. In the 2000 s, participation was online and there were requirements to participate regularly and to undertake learning activities. Although not all learning activities were assessed, they were moni- 
tored. Expectations were therefore raised regarding participation. While this reduces flexibility, it did help me to learn.

\section{Assessment}

Assessments for online courses in the 1980s were normally in the form of written assessments or examinations. Written assessments included problem solving, creating computer programs or writing essays. Table 3 provides a comparison of the flexibility between assessment practices for the two periods. New technologies facilitated a much wider variety of assessments than had been possible in the 1980s.

Although assessment criteria in both years were fixed, there was no reason why they could not have been negotiated. All my assignments in the 1980s were individual, whereas my recent studies included opportunities to work cooperatively with my fellow students in group projects. I like to have my students work in groups, so I was surprised at how negatively I approached the idea of a group project. The group project meant less flexibility in time, fixed times when we needed to work and fixed schedules that had to suit others. I found it quite confronting to have my grade dependent on the work of others. The actual experience of group work was positive, however. It was fun to work with others and we were able to meet up face-to-face as well as online. We were all motivated and brought different experiences and backgrounds to the group, which worked well.

\begin{tabular}{|c|c|c|}
\hline \multicolumn{3}{|c|}{ Table 3: Comparison of flexibility for assessment category } \\
\hline Flexibility Dimension & 1982-1983 experience & 2007-2008 experience \\
\hline $\begin{array}{l}\text { Assessment methods } \\
\text { fixed or choice }\end{array}$ & $\begin{array}{l}\text { Fixed - sometimes choice of topics for } \\
\text { essays }\end{array}$ & $\begin{array}{l}\text { Some choice given in choice of as- } \\
\text { sessments or topics }\end{array}$ \\
\hline Types of assessment & $\begin{array}{l}\text { Written assessments - either short } \\
\text { questions or essays. } \\
\text { Examinations }\end{array}$ & \begin{tabular}{ll}
\multicolumn{2}{l}{ Variety of assessments including: } \\
- & Essays \\
- & Analyses of articles \\
- & Online Quizzes \\
- & Discussions \\
- & Group project \\
- & Reflections \\
- & Research project
\end{tabular} \\
\hline $\begin{array}{l}\text { Assessment criteria } \\
\text { fixed or negotiated }\end{array}$ & Fixed & Fixed \\
\hline $\begin{array}{l}\text { Individual / Group } \\
\text { assignments }\end{array}$ & Individual & $\begin{array}{l}\text { Mostly individual but some group } \\
\text { activities and one group project }\end{array}$ \\
\hline
\end{tabular}

\section{Instructional Approach}

Not surprisingly as shown in Table 4, the range of instructional approaches used, the technologies used, and the different formats for learning materials were much more varied in 2008 than they were in 1983. It was also much easier and more immediate to find materials. Although these different approaches were used in different units in my recent studies, students were largely not given any choices. We were told what to study and in what format. Sadler-Smith and Smith (2004) differentiate between instructive designs that are adaptive, where a range of options are available to cater for different students' learning styles, and those that are non-adaptive, where a range of styles might be used so that all learners are accommodated, but that the learner needs to cope with the different designs. The adaptive style would offer students the choice between watching a video or reading an article, for example, whereas the non-adaptive style would sometimes use video and at other times use articles. The approach used in my recent experience was semi-adaptive - although the student was given little choice, but there were a variety of learning approaches used. My experience in the 1980s was that styles used were limited. They were 
mostly text-based, and the instructor's role was that of an expert rather than adapting from expert, to fellow investigator, to facilitator.

\begin{tabular}{|c|c|c|}
\hline Flexibility Dimension & 1982-1983 experience & 2007-2008 experience \\
\hline $\begin{array}{l}\text { Social organisation of } \\
\text { learning }\end{array}$ & $\begin{array}{l}\text { Organised for individual learning. At } \\
\text { times found someone doing the same } \\
\text { subject and worked together in study- } \\
\text { ing for exams. }\end{array}$ & $\begin{array}{l}\text { Group activities and discussions en- } \\
\text { couraged. Individual work also re- } \\
\text { quired. }\end{array}$ \\
\hline $\begin{array}{l}\text { Formats of learning } \\
\text { materials }\end{array}$ & $\begin{array}{l}\text { Textbooks } \\
\text { Paper-based materials } \\
\text { Articles/reference books available in } \\
\text { paper-based form by ordering from } \\
\text { library }\end{array}$ & $\begin{array}{l}\text { Textbooks } \\
\text { Online learning materials } \\
\text { Articles and book chapters available } \\
\text { online } \\
\text { Videos available online }\end{array}$ \\
\hline $\begin{array}{l}\text { Role of the instructor } \\
\text { (Note that neither sub- } \\
\text { ject had tutors) }\end{array}$ & $\begin{array}{l}\text { Subject expert } \\
\text { Wrote materials } \\
\text { Answered questions (rarely) } \\
\text { Prepared and marked assessments } \\
\text { Provided feedback to students }\end{array}$ & $\begin{array}{l}\text { Subject expert } \\
\text { Wrote online materials } \\
\text { Facilitator (in online discussions - } \\
\text { answering and asking questions) } \\
\text { Prepared and marked assessments } \\
\text { Provide feedback to students }\end{array}$ \\
\hline $\begin{array}{l}\text { Feedback methods } \\
\text { from instructor }\end{array}$ & $\begin{array}{l}\text { Hand written on submitted assign- } \\
\text { ments }\end{array}$ & $\begin{array}{l}\text { Hand written on assignments } \\
\text { Discussion boards } \\
\text { Computer Quiz } \\
\text { Telephone discussions (e.g.. for project } \\
\text { proposal for research project) }\end{array}$ \\
\hline
\end{tabular}

Collaborative learning was not built into the learning experiences in the 1980s but was a definite expectation in the 2000s. We were expected to participate in discussions, chats, and various online activities. We were graded on our participation and interaction with others in the class. We were expected to bring our own experiences into the learning. The collaborative experience was definitely a positive experience for me and I valued learning from others. The need to explain my reasoning to others also helped to develop my thinking.

\section{Course Delivery}

Technologies for communication with the lecturer and with other students have improved exponentially over the past 30 years. As shown in Table 5, there were many more ways in which we could communicate with the lecturer, and this allowed students to communicate in different ways that worked best for them. Some of the lecturers had special discussion forums for asking students questions, and this was very helpful as it allowed all students to see what someone had asked and what the lecturer had responded. Flexibility with regard to place was not improved dramatically, however, as I found myself printing off materials to read on the train or in doctor's offices. The laptop computer instead of a desktop one did give a bit more flexibility with regard to using the computer in a variety of places.

\begin{tabular}{|l|l|l|}
\hline \multicolumn{2}{|c|}{ Table 5: Comparison of flexibility for course delivery category } \\
\hline Flexibility Dimension & $\mathbf{1 9 8 2 - 1 9 8 3}$ experience & $\mathbf{2 0 0 7 - 2 0 0 8}$ experience \\
\hline $\begin{array}{l}\text { Communication with } \\
\text { the lecturer }\end{array}$ & Letter, telephone & $\begin{array}{l}\text { Email, discussion boards, telephone, tele- } \\
\text { conferences }\end{array}$ \\
\hline $\begin{array}{l}\text { Types of support avail- } \\
\text { able }\end{array}$ & Lecturer, library & $\begin{array}{l}\text { Lecturer, academic support, library, tech- } \\
\text { nical support, fellow students }\end{array}$ \\
\hline Place for study & $\begin{array}{l}\text { Home, bus, reading material could } \\
\text { be taken with you, computer fixed }\end{array}$ & $\begin{array}{l}\text { Download reading materials if use re- } \\
\text { motely } \\
\text { Home, train, laptop computer }\end{array}$ \\
\hline
\end{tabular}




\section{Time}

Time is one of the categories that does not seem to have improved as technology has progressed over the past 30 years as shown in Table 6 . In some ways it has reduced flexibility. In one unit, we were expected to participate in a discussion group each week after reading the week's materials. For someone who is a dependent learner with set hours each week that they are able to study this may be fine, but it caused me much stress as I tried to juggle my competing responsibilities.

\begin{tabular}{|l|l|l|}
\hline \multicolumn{2}{|c|}{ Table 6: Comparison of flexibility for time category } \\
\hline Flexibility Dimension & $\mathbf{1 9 8 2 - 1 9 8 3 ~ e x p e r i e n c e ~}$ & $\mathbf{2 0 0 7 - 2 0 0 8}$ experience \\
\hline Starting time of subject & $\begin{array}{l}\text { Flexible from time of enrolment to } \\
\text { start of assessment period }\end{array}$ & Week 1 of semester \\
\hline $\begin{array}{l}\text { Times for participation } \\
\text { within the subject }\end{array}$ & $\begin{array}{l}\text { No specific times for participation } \\
\text { except examination }\end{array}$ & $\begin{array}{l}\text { Participation expected each } \\
\text { week/fortnight in online discussions, } \\
\text { teleconferences, etc }\end{array}$ \\
\hline $\begin{array}{l}\text { Learners pace them- } \\
\text { selves }\end{array}$ & $\begin{array}{l}\text { Guidelines based around assessment } \\
\text { but not specified }\end{array}$ & $\begin{array}{l}\text { Participation expectations meant that } \\
\text { you had to work at the pace specified }\end{array}$ \\
\hline Timing of assessment & Fixed assessment dates & Fixed assessment dates \\
\hline
\end{tabular}

\section{Learning Styles}

Some of the sentiments expressed in the learning styles category overlap with what has gone before, and that is not surprising. As indicated in Table 7, my experiences in 2008 showed a greater variety of modes used for learning and a greater emphasis on collaboration. This is a positive trend. Where the trend seems negative is that the way in which the learning was structured in 2008 seems to be focussed on the dependent learner. The learning told you what to study, when it needed to be studied, where to find the materials, and how you had to participate each week. I found this frustrating and restrictive but can understand how it would be helpful to someone who was not able to self-direct their own learning.

\begin{tabular}{|l|l|l|}
\hline \multicolumn{3}{|c|}{ Table 7: Comparison of flexibility for learning styles category } \\
\hline Flexibility Dimension & $\mathbf{1 9 8 2 - 1 9 8 3 ~ e x p e r i e n c e ~}$ & $\mathbf{2 0 0 7 - 2 0 0 8}$ experience \\
\hline $\begin{array}{l}\text { Autonomy (dependent } \\
\text { vs independent learner) }\end{array}$ & $\begin{array}{l}\text { Had to be an independent learner. } \\
\text { Dependent learners would have } \\
\text { struggled and many would have } \\
\text { dropped out. }\end{array}$ & $\begin{array}{l}\text { Seems to be more geared towards the } \\
\text { dependent learner than the independent } \\
\text { learner. Scaffolds learning and requires } \\
\text { participation at particular times in } \\
\text { specific ways. }\end{array}$ \\
\hline $\begin{array}{l}\text { Mode preference (ver- } \\
\text { bal vs visual) }\end{array}$ & Mostly Verbal & $\begin{array}{l}\text { Both modes used but generally re- } \\
\text { quired to use one or the other not both. }\end{array}$ \\
\hline $\begin{array}{l}\text { Collaborative vs Indi- } \\
\text { vidual }\end{array}$ & $\begin{array}{l}\text { Mostly individual, anything under- } \\
\text { taken collaboratively was not facili- } \\
\text { tated by the distance learning }\end{array}$ & $\begin{array}{l}\text { Combination of individual and col- } \\
\text { laborative work. Collaboration was } \\
\text { encouraged and assessed. }\end{array}$ \\
\hline
\end{tabular}

\section{Implications and Future Research}

What does this mean for online course designers? Although the author's experience is that of one student, would others experience it in the same way? The author recognises that a different person with their own specific learning styles might have had a totally different experience to her own. This is something for future research.

There have been a lot of positives over the past 30 years. Technology has helped to give lecturers and students options regarding how, where, when, and what they study. This was evident in my experiences where a variety of learning experiences and technologies were used to offer a rich learning experience compared to that of my earlier studies in the $1980 \mathrm{~s}$. 
There was, however, very little choice for students to determine what learning method they wanted to use for a particular part of the course. Sadler-Smith and Smith (2004) suggest that this is necessary in order for truly flexible learning. On the other hand, we want students who are able to adapt themselves and to work in different paradigms, use a variety of technologies, and work both independently and collaboratively. If we only provided students with their preferences, would we be reducing their ability to work flexibly themselves?

Looking to the literature, some of the issues that the author experienced have been suggested by others. Brindley, Walti and Blasschke (2009, p.13-14) note that "Learners who choose online study most often do so because of the flexibility and convenience of choosing their own study hours, usually because they have very busy lives. Particularly in the case of adult learners, other roles may be primary to that of student. Academic work is important but must fit around demands of career, home, and community. Group projects require that learners be present on a particular schedule, reducing the flexibility and convenience factor in online study and may cause anxiety and/or resentment, particularly if the purpose of the group work is not clear and the group experience is not positive." This is confirmed by Dalsgaard (2005) who says that it is possible to have flexibility of time and space if students work individually but where active collaboration is required the students have to work interdependently and that means that there needs to be coordination, resulting in a reduction in flexibility.

On the other hand, should online learners be deprived of social learning because they do not come on campus? As Brindley et al. (2009) suggest, learning should take place in a rich environment that offers opportunity for interaction and connectedness. There are many studies that confirm that interaction among students improves learning and enhances critical thinking in the online environment (Baggaley, 2008; Bassett, 2011; Brindley et al., 2009; Menchaca \& Bekele, 2008). Being able to work collaboratively is one of our university's graduate attributes. We say that we develop this attribute through our courses. If we allow students to choose between working individually and working with others, we would be saying that those who work online do not need to develop this capability. Even in my own experience, I was negative about doing group assignments at first, but found that I was able to learn so much more through the collective expertise of the group that it was a worthwhile activity.

In a study of 552 students undertaking studies using print-based distance learning, web-based distance learning, and face-to-face classes, Hagel and Shaw (2006) found that online delivery was not better than print-based delivery for convenience, time-efficiency, or flexibility. They also found that web-based delivery was not able to bridge the gap in students' perceptions of engagement compared to on-campus learning. When staff tried to make units more engaging then distance students often lost what they valued most about studying at a distance - namely autonomy and convenience.

Bassett (2011), however, found that structuring discussions helped students to participate more effectively and students valued the collaborative experience. Students need to be made aware of their own learning styles as this will help them to identify their strengths and weaknesses and to adapt to the pressures of different learning requirements for their courses (Sadler-Smith \& Smith, 2004). Lecturers should provide different learning experiences, but learners should also be able to adapt and be flexible in their learning.

\section{Conclusion}

As Willems (2005, p.245) says, "Flexible provision does not necessarily equate with effective learning, as simply providing a range of options does not bring with it deep learning. Students need ongoing support in how to operate in these various environments and how to effectively learn within them." 
Constructivist theory encourages educators to involve students in social and practical activities in order to improve their learning. Educators are embracing technology as a way of supplementing other learning methods of engaging the students. As we increase engagement and activity we may be reducing flexibility as we require students to interact with others or participate in activities at a particular time.

It is impossible for educational designers to offer every student their preferred method of studying. Nevertheless they need to be aware that they have a variety of students in their class and that they may need to build in flexibility to cater for the diversity of students' learning styles and to fit in with the peaks and troughs of competing activities. The onus is not only on the lecturer, however. Students also need to learn to work with a diversity of other students in a variety of settings. Students may need help in order to cope with working outside of their comfort zone.

There is no simple recommendation for improving flexibility of e-learning. As one dimension of flexibility is improved, another may be reduced. The question remains, how do we improve interaction, a sense of presence and connectedness, and promote group activities while still allowing distance students the flexibility that they require to work around work and family commitments? This question deserves further research.

In hindsight, would I as a student have swapped the interactive discussions and the group activities for more flexibility? No, I would not. A great deal of learning took place by interacting with fellow students and learning from them. Was I stressed? Yes, I was. Was it worth the stress? Yes, it was. Could we do it better? Yes, we can.

\section{References}

Ardito, C., Costabile, M., de Marsico, M., Lanzilotti R., Levialdi S., Roselli, T., \& Rossano, V. (2006). An approach to usability evaluation of e-learning applications. Universal Access in the Information Society, 4(3), 270-283.

Baath, J. (1982). Distance students' learning — Empirical findings and theoretical deliberations. Distance Education, 3(1), 6 -27.

Baggaley, J. N. (2008). Where did distance education go wrong? Distance Education, 29(1), 39-51.

Bassett, P. (2011). How do students view asynchronous online discussions as a learning experience? Interdisciplinary Journal of e-Learning and Learning Objects, 7, 69-79. Retrieved 5 May 2012 from http://www.ijello.org/Volume7/IJELLOv7p069-079Bassett744.pdf

Bennett, S., Agostinho, S., Lockyer, L., \& Harper, B. (2009). Researching learning design in open, distance, and flexible learning: Investigating approaches to supporting design processes and practices. Distance Education, 30(2), 175-177.

Bowles, M.S. (2004). Learning to E-Learn Project: Rediscovering the benefits of e-learning. Unitas Knowledge Centre. Retrieved 5 May 2012 from http://www.marcbowles.com/ifwf/Portals/0/Future\%20and\%20Elearning\%20ICETA2004.pdf

Brindley, J. E., Walti, C., \& Blaschke, L.M. (2009). Creating effective collaborative learning groups in an online environment. International Review of Research in Open and Distance Learning, 10(3), 1-18.

Dalsgaard, B. (2005). Pedagogical quality in e-learning. E-Learning and Education Journal (1). Retrieved 27 February 2012 from https://eleed.campussource.de/archive/1/78/index html/

Hagel, P., \& Shaw, R. N. (2006). Students' perceptions of study modes. Distance Education, 27(3), 283302.

Marland, P. W., \& Store, R. E. (1982). Some instructional strategies for improved learning from distance teaching materials. Distance Education, 3(1), 72 - 106. 
Menchaca, M. P., \& Bekele, T. A. (2008). Learner and instructor identified success factors in distance education. Distance Education, 29(3), 231 - 252.

Nikolova, I. \& Collis, B. (1998). Flexible learning and design of instruction. British Journal of Educational Technology, 29(1), 59-72.

Ozkan, S., \& Koseler, R. (2009). Multi-dimensional students' evaluation of e-learning systems in the higher education context: An empirical investigation. Computers \& Education, 53, 1285-1296.

Sadler-Smith, E. \& Smith, P. (2004) Strategies for accommodating individual's styles and preferences in flexible learning programmes. British Journal of Educational Technology, 35, 395-412.

Tremblay, R. (2006). Technical evaluation report 55: Best practices and collaborative software in online teaching. International Review of Research in Open and Distance Learning, 7(1), 1-5.

Van den Brande, L. (1993). Flexible and distance learning - A special report. Wiley and Commission of the European Communities Directorate-General XIII, Brussels.

Willems, J. (2005). Flexible learning: Implications of "when-ever", "where-ever" and "what-ever". Distance Education, 26(3), 429-435.

\section{Biography}

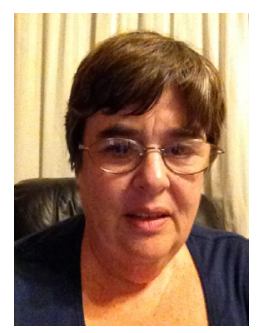

Dr Theda Thomas is Associate Dean (Learning and Teaching) at the Australian Catholic University and has held this position since 2007. She started her career working as a computer programmer at Ford Motor Company and then at the University of South Africa. She moved to teaching in the tertiary sector in 1987 and worked for many years at the Port Elizabeth Technikon (now known as the Nelson Mandella Metropolitan University) as a senior lecturer and Head of Department of Information Systems. She obtained her doctorate from the University of Pretoria in 2001.

Dr Thomas started publishing on learning and teaching in Information Systems in the late 1990s and has continued this interest in higher education research since this time. Her research investigated ways of developing non-technical skills (communication skills, interpersonal skills, critical thinking skills) required by Information Systems professionals.

Over the past few years she has expanded her research into developing graduate attributes across a wide range of discipline areas. 